Supporting information for

\title{
Speciation of Adsorbed Phosphate at Gold Electrodes: A Combined Surface-Enhanced Infrared Absorption Spectroscopy and DFT Study
}

\author{
Momo Yaguchi, ${ }^{1,2}$ Taro Uchida, ${ }^{3}$ Kenta Motobayashi, ${ }^{1}$ and Masatoshi Osawa*1 \\ ${ }^{1}$ Institute for Catalysis, Hokkaido University, Sapporo 00-1-0021, Japan \\ ${ }^{2}$ Graduate School of Environmental Science, Hokkaido University, Sapporo 060-0810, Japan \\ ${ }^{3}$ Center for Energy and Environmental Science, Shinshu University, Nagano 390-8621, Japan \\ osawam@cat.hokudai.ac.jp
}




\section{Experimental Methods:}

The SEIRAS-active $\mathrm{Au}$ thin-film working electrode, $c a .75 \mathrm{~nm}$ thickness, was synthesized on a triangular non-doped Si prism (Pier Optics) by a 'double-deposition' method. An Au thin-film was first prepared by following the previously reported chemical deposition technique ${ }^{1}$. The as-prepared Au thin-film was dissolved with $200 \mu \mathrm{m}$ of aqua regia to get the bare Si surface with a trace of Au seeds. Subsequently, Au was re-deposited on the $\mathrm{Si}$ prism by the same chemical deposition technique ${ }^{1}$ as before. The spectroelectrochemical cell used in this study was a three-compartment glass cell, $\sim 35 \mathrm{~mL}$ in volume, equipped with a $\mathrm{Pt}$ foil and a $\mathrm{Ag} / \mathrm{AgCl} / \mathrm{Sat} . \mathrm{KCl}$ (BAS Inc.) served as the counter and reference electrodes, respectively. The Au-coated Si prism was attached to the cell sandwiching an O-ring $\left(\mathrm{Karlez}^{\mathbb{R}}\right)$. All potentials are given on the reversible hydrogen electrode (RHE) scale unless otherwise noted. Prior to each measurement, the Au electrode surface was cleaned in $0.1 \mathrm{M} \mathrm{H}_{2} \mathrm{SO}_{4}$ by cycling the potential between 0.4 and $1.7 \mathrm{~V}$ (vs. RHE) until a stable voltammogram was obtained.

SEIRA spectra were recorded with a FT-IR spectrometer (Bio-Rad, FTS-60A/896) equipped with an $\mathrm{HgCdTe}(\mathrm{MCT})$ detector and a homemade single-reflection accessory (incident angle of $60^{\circ}$ ). The spectrometer was operated in kinetic mode with a spectral resolution of $4 \mathrm{~cm}^{-1}$ and a time-resolution of $0.78 \mathrm{~s}$, while electrochemical measurements with a potentiostat (AMETEK, VersaSTAT 3) were carried out simultaneously. All spectra were calculated in absorbance units defined as $-\log \left(I_{\text {sample }} / I_{\text {ref }}\right)$, where $I_{\text {sample }}$ and $I_{\text {ref }}$ stand for the spectra at sample and reference potentials. Accordingly, the upward bands correspond to the species adsorbed on the electrode.

The supporting electrolytes employed were $0.1 \mathrm{M}$ aqueous phosphate buffer solutions ( $\mathrm{pH}$ 2-12) prepared from phosphoric acid (Suprapure, Merck), sodium dihydrogenphosphate (Suprapure, Merck), sodium hydrogenphosphate (Suprapure, Merck), and/or sodium phosphate (Wako Pure Chemicals). All solutions were made using $18 \mathrm{M} \Omega$. $\mathrm{cm}$ Milli-Q water except for the isotopic study in which $\mathrm{D}_{2} \mathrm{O}$ (Sigma Aldrich) was used. The electrolyte solutions were deaerated with Ar for at least one hour prior to experiments. All experiments were carried out at room temperature. 


\section{Calculation Methods:}

Harmonic vibrational frequencies of the phosphate species adsorbed on $\mathrm{Au}(111)$ surfaces were calculated by DFT using a cluster consisting of $19 \mathrm{Au}$ atoms arranged in three layers of $12+6+1$ atoms or two layers of $12+7$ atoms. A phosphate species (either $\mathrm{HPO}_{4}$ or $\mathrm{PO}_{4}$ ) was located at the center of the clusters ( $f c c$ site for the former and $h p c$ site for the latter). Solution was described by the conductor-like polarizable continuum model $(\mathrm{CPCM})^{2}$ with the dielectric constant of water. Geometry optimization of the adsorbed system was carried out starting from different configurations in the presence of an external electric field $(F)$ of $-1 \times 10^{2} \sim 1 \times 10^{2} \mathrm{~V} \mathrm{~nm}^{-1}$ using the B3LYP functional in combination with $6-31+\mathrm{G}(\mathrm{d}, \mathrm{p})$ basis set for $\mathrm{P}, \mathrm{O}$, and $\mathrm{H}$ atoms and the LanL2DZ effective core potential for describing the gold metal atoms, as implemented in Gaussian 09, Revision E.01. ${ }^{3}$. The geometry of the metal cluster was kept fixed during the optimization, with the gold nuclei located at their position in the truncated crystal, and the same distance between neighboring gold atoms as that in the bulk metal $(0.28837 \mathrm{~nm})$.

(1) Miyake, H.; Ye, S.; Osawa, M., Electroless Deposition of Gold Thin Films on Silicon for Surface-Enhanced Infrared Spectroelectrochemistry. Electrochem. Commun. 2002, 4, 973-977.

(2) Cossi, M.; Rega, N.; Scalmani, G.; Barone, V., Energies, Structures, and Electronic Properties of Molecules in Solution with the C-PCM Solvation Model. J. Comput. Chem. 2003, 24, 669-681.

(3) M. J. Frisch, G. W. Ttucks., H. B. Schlegel, G. E. Scuseria, M. A. Robb, J. R. Cheeseman, G. Scalmani, V. Barone, B. Mennucci, G. A. Petersson, H. Nakatsuji, M. Caricato, X. Li, H. P. Hratchian, A. F. Izmaylov, J. Bloino, G. Zheng, J. L. Sonnenberg, M. Hada, M. Ehara, K. Toyota, R. Fukuda, J. Hasegawa, M. Ishida, T. Nakajima, Y. Honda, O. Kitao, H. Nakai, T. Vreven, J. A. Montgomery, Jr., J. E. Peralta, F. Ogliaro, M. Bearpark, J. J. Heyd, E. Brothers, K. N. Kudin, V. N. Staroverov, R. Kobayashi, J. Normand, K. Raghavachari, A. Rendell, J. C. Burant, S. S. Iyengar, J. Tomasi, M. Cossi, N. Rega, J. M. Millam, M. Klene, J. E. Knox, J. B. Cross, V. Bakken, C. Adamo, J. Jaramillo, R. Gomperts, R. E. Stratmann, O. Yazyev, A. J. Austin, R. Cammi, C. Pomelli, J. W. Ochterski, R. L. Martin, K. Morokuma, V. G. Zakrzewski, G. A. Voth, P. Salvador, J. J. Dannenberg, S. Dapprich, A. D. Daniels, Ö. Farkas, J. B. Foresman, J. V. Ortiz, J. Cioslowski, and D. J. Fox Gaussian 09, Revision E.01., Gaussian, Inc.: Wallingford CT, 2013. 

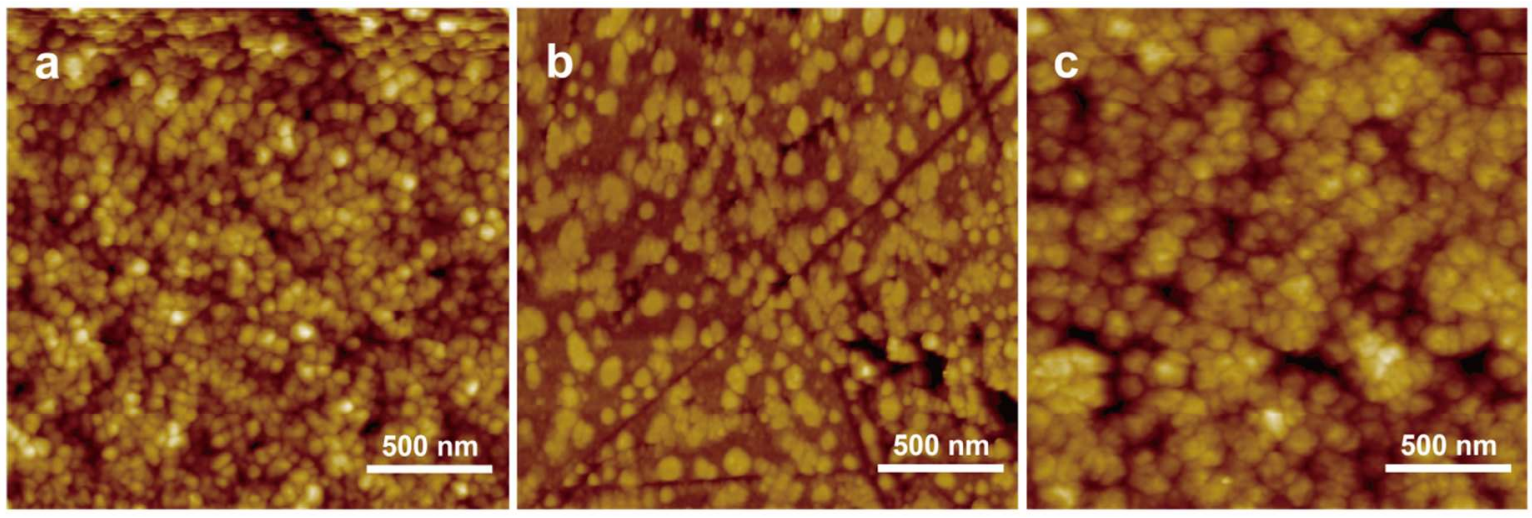

Figure S1. Atomic force microscopy (AFM) images of (a) an Au on a Si substrate after the first chemical deposition, (b) a Si surfaces after the as-prepared Au thin-film was treated and dissolved with aqua regia, and (c) an Au chemically deposited on the aqua regia treated Si substrate.

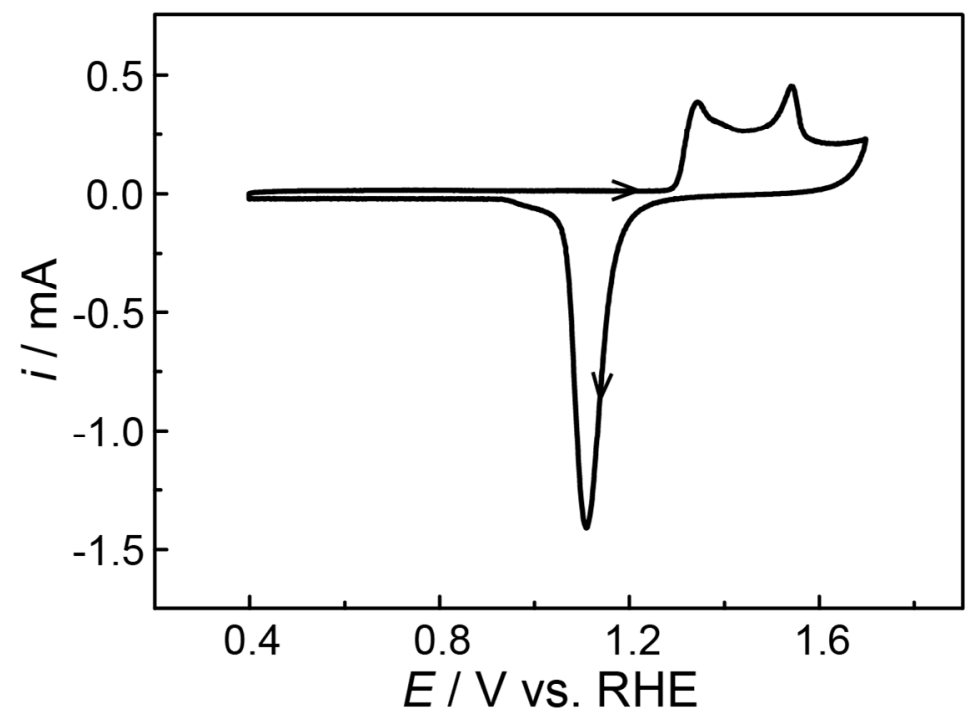

Figure S2. Cyclic Voltammogram of a SEIRAS-active Au thin-film electrode recorded in $0.1 \mathrm{M} \mathrm{H}_{2} \mathrm{SO}_{4}$ at $50 \mathrm{mV} \mathrm{s}^{-1}$ during a potential sweep from 0.4 to 1.7 and back to $0.4 \mathrm{~V}$ vs. RHE. 

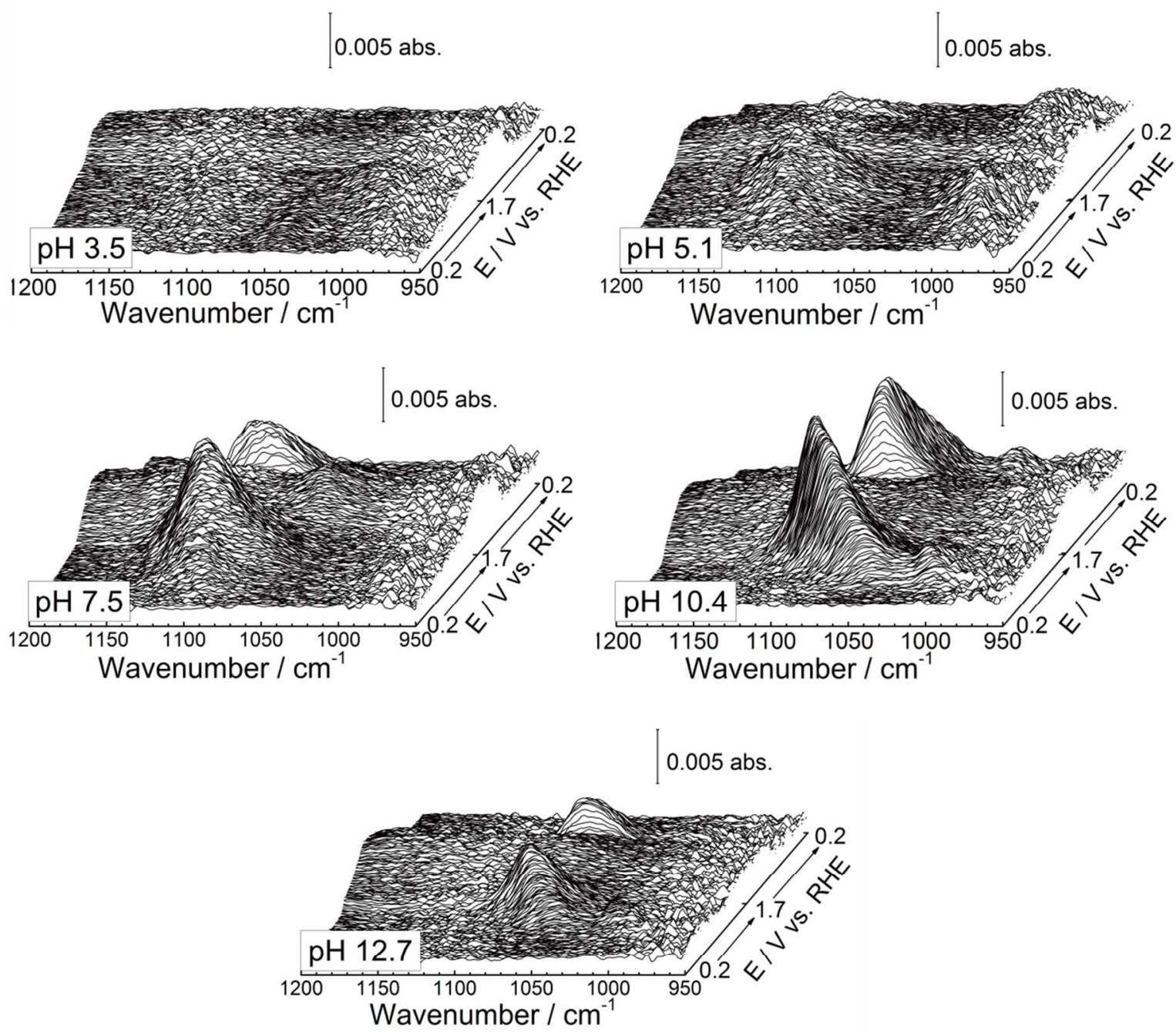

Figure S3. SEIRA spectra of Au thin-film electrodes acquired in $0.1 \mathrm{M}$ phosphate buffer electrolytes with $\mathrm{pH} 3.5,5.1,7.5,10.4$ and 12.7 during a potential sweep from 0.2 to 1.7 and back to $0.2 \mathrm{~V}$ vs. RHE at a scan rate of $10 \mathrm{mV} \mathrm{s}^{-1}$ with a time resolution of $0.78 \mathrm{~s}$ in the spectral range of $950-1200 \mathrm{~cm}^{-1}$. The reference spectrum was taken at $0.2 \mathrm{~V}$ in advance for all conditions. 


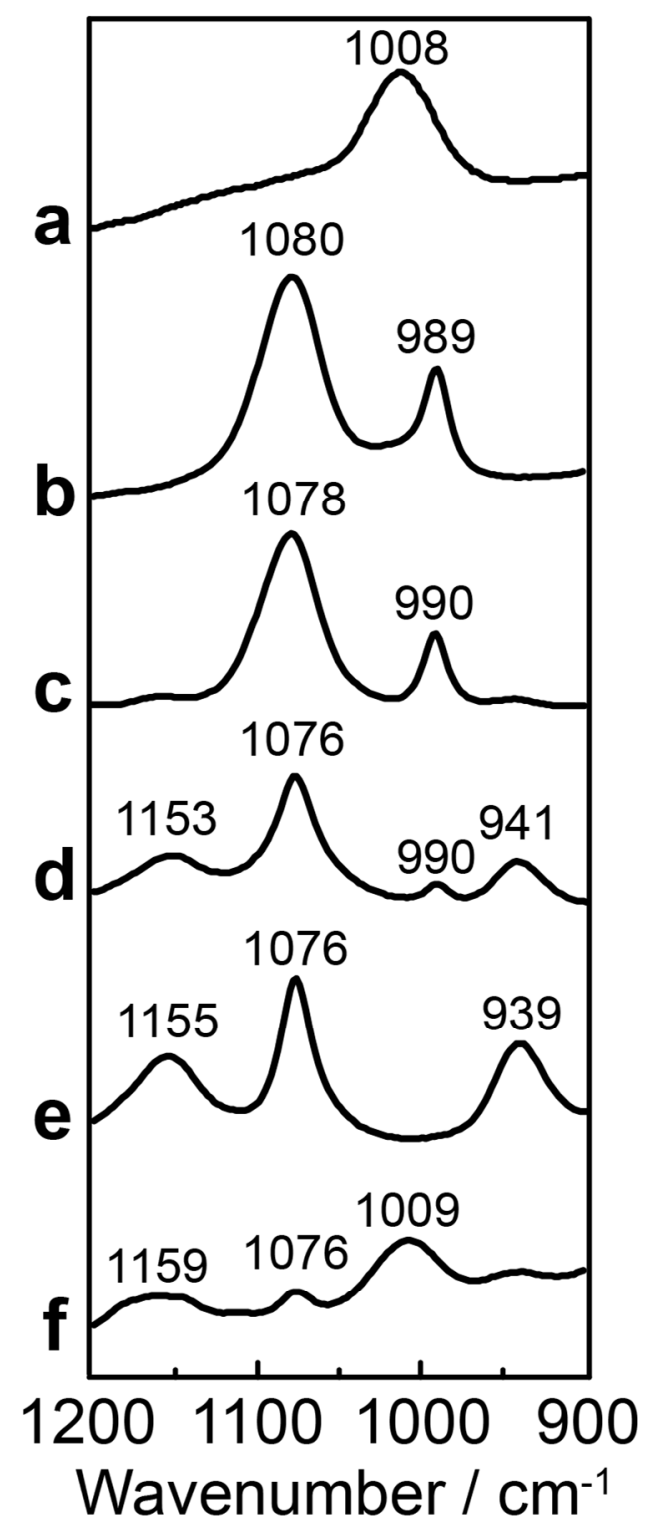

Figure S4. Standard ATR-IR spectra of $0.5 \mathrm{M}$ phosphate buffer solutions with $\mathrm{pH}$ (a) 12.7 (b) 10.1 (c) 7.3 (d) 6.0 (e) 5.0 and (f) 1.5 . 

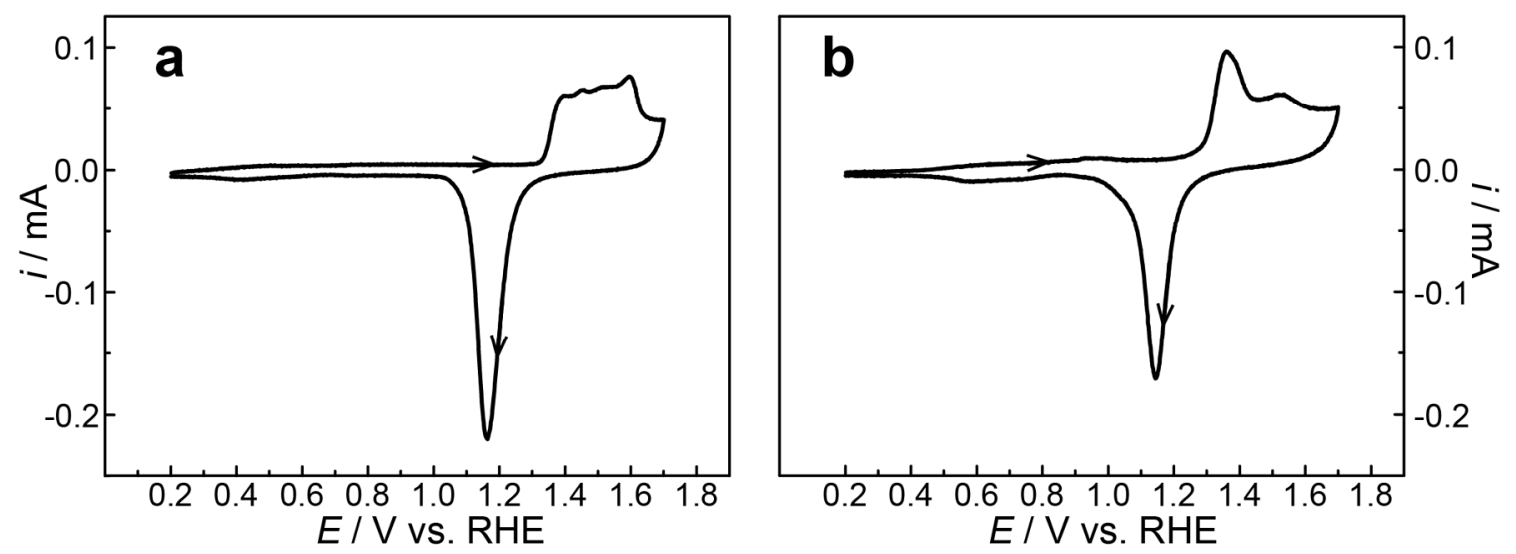

Figure S5. Cyclic voltammograms of an Au thin-film electrode in $0.1 \mathrm{M}$ phosphate buffer electrolyte at $\mathrm{pH}$ (a) 5.1 and (b) 10.4 during a potential sweep from 0.2 to 1.7 and back to $0.2 \mathrm{~V}$ vs. RHE at $10 \mathrm{mV} \mathrm{s}^{-1}$.
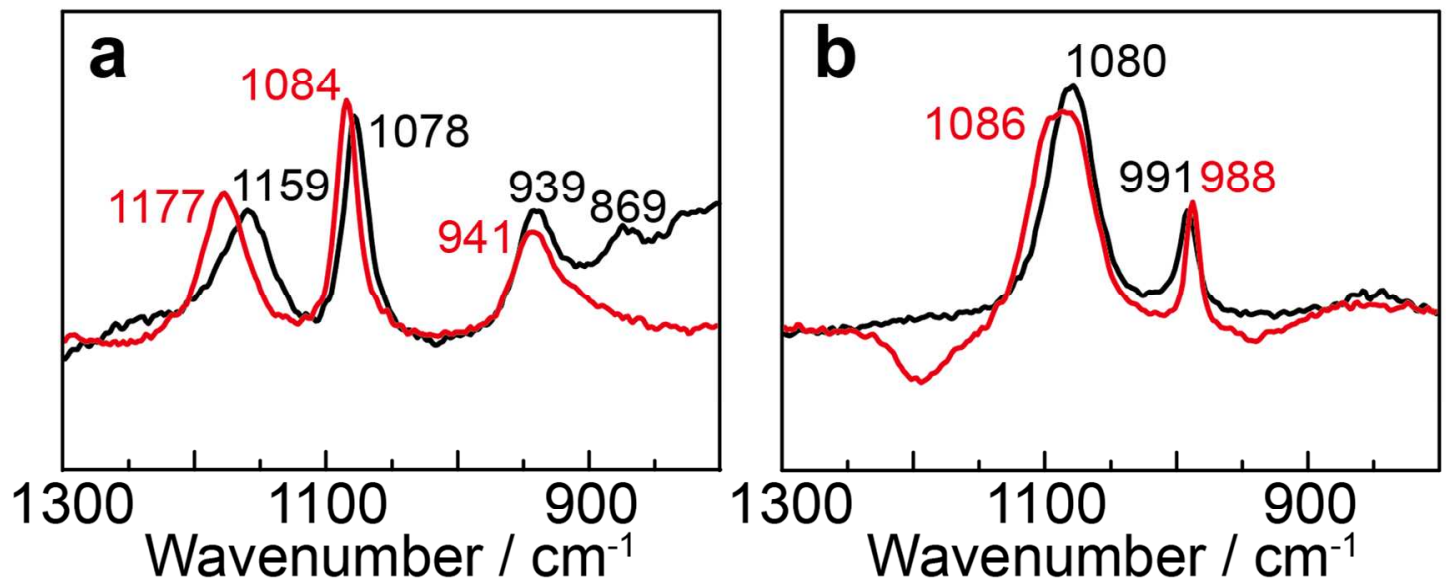

Figure S6. Standard ATR-IR spectra of $0.1 \mathrm{M}$ phosphate buffer solutions at $\mathrm{pH}$ (a) 5 $\left(\mathrm{H}_{2} \mathrm{PO}_{4}{ }^{-}\right.$dominant) and (b) $10\left(\mathrm{HPO}_{4}{ }^{2-}\right.$ dominant) prepared with $\mathrm{H}_{2} \mathrm{O}$ (black) or $\mathrm{D}_{2} \mathrm{O}$ (red). 

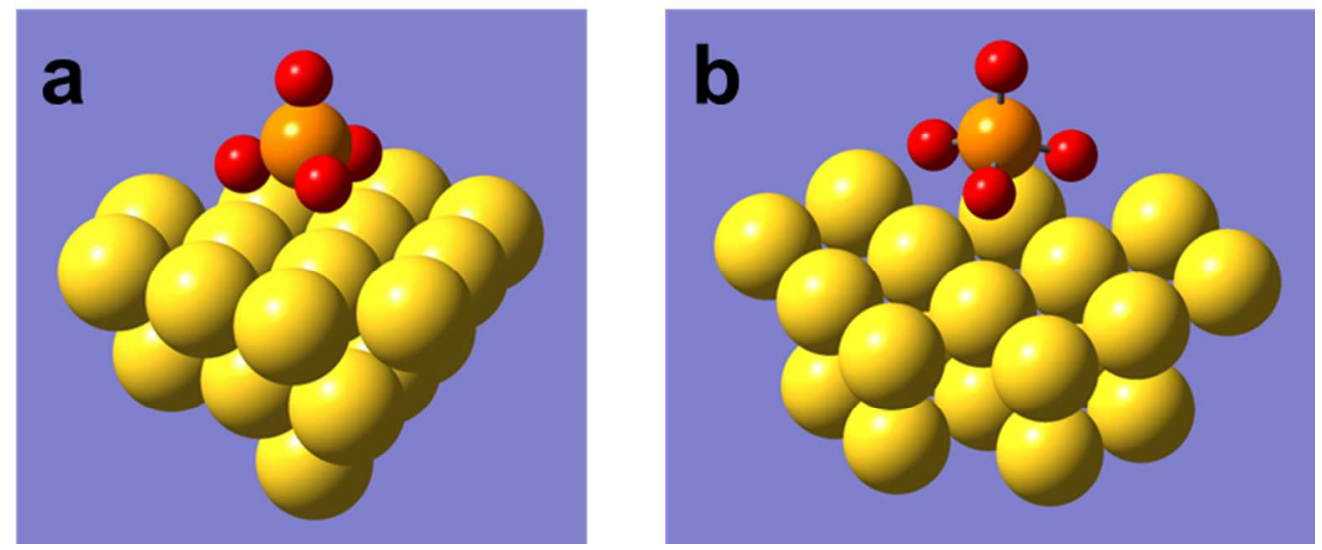

Figure S7. Optimized geometries for the $\mathrm{PO}_{4}$ species adsorbed on $\mathrm{Au}_{19}$ clusters with (a) 12-6-1 and (b) 12-7 structures. The centers of the clusters are $f c c$ and hcp sites, respectively. Similar structures were calculated for the $\mathrm{HPO}_{4}$ species.

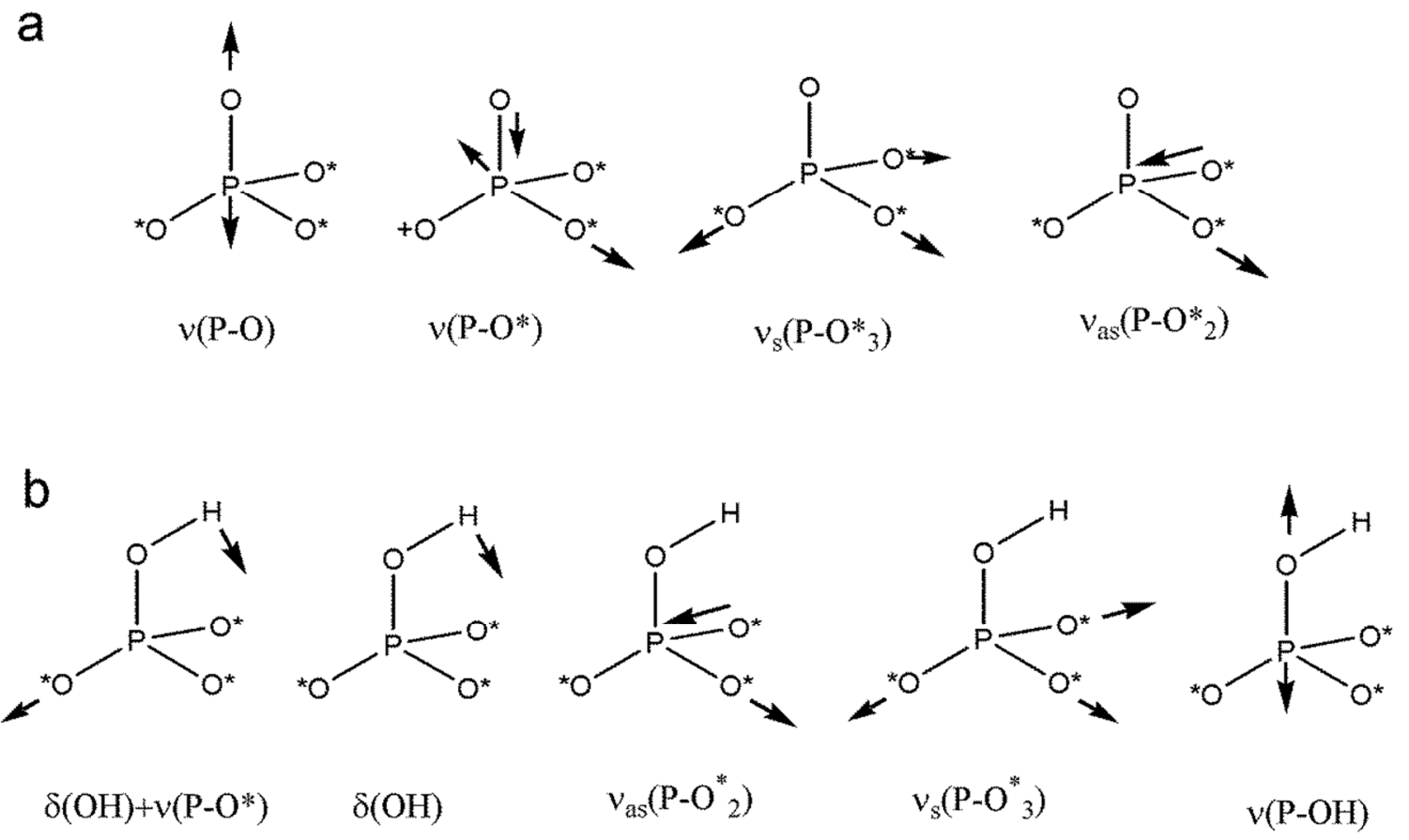

Figure S8. Vibrational modes of the adsorbed (a) $\mathrm{PO}_{4}$ and (b) $\mathrm{HPO}_{4}$ species. O* denotes the oxygen atom coordinated to Au surfaces. 


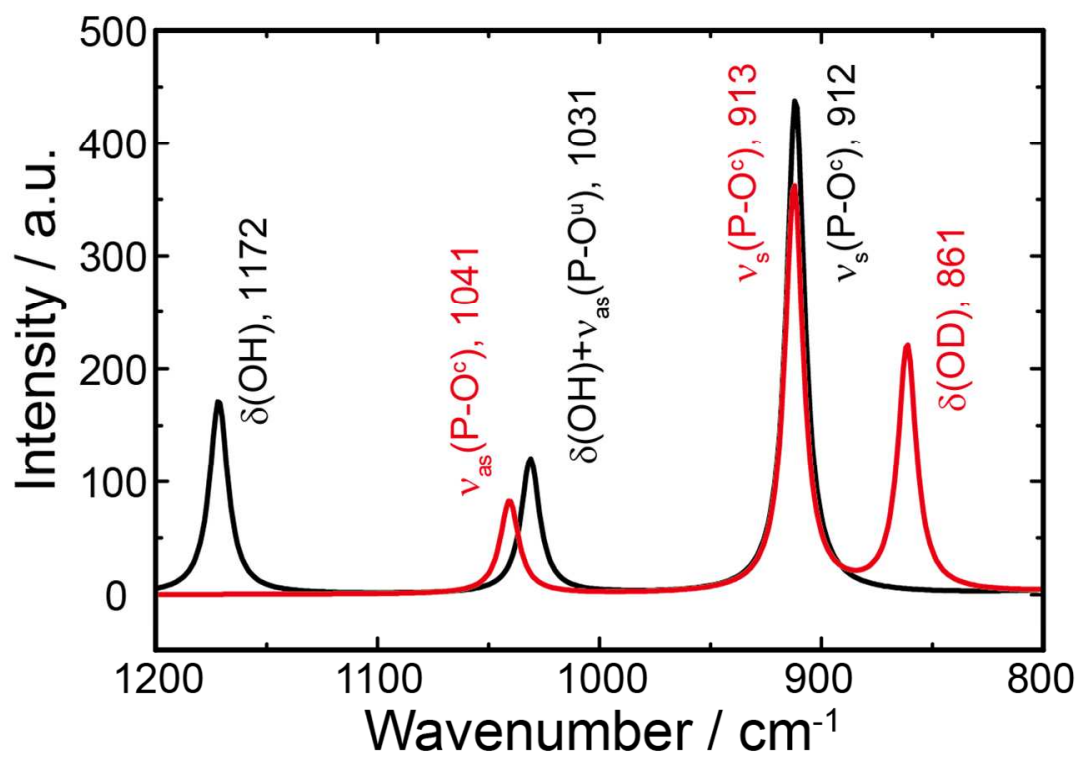

Figure S9. Computed IR spectra of the adsorbed $\mathrm{H}(\mathrm{D}) \mathrm{PO}_{4}$ species on $\mathrm{Au}(111)$ surfaces in $\mathrm{H}_{2} \mathrm{O}$, black, and $\mathrm{D}_{2} \mathrm{O}$, red, including the hydrogen bonding between the $\mathrm{OH}(\mathrm{D})$ moiety and a $\mathrm{H}(\mathrm{D})_{2} \mathrm{O}$ molecule. No electric field was applied in the calculation. 
Table S1. Experimentally observed vibrational frequencies $\left(\mathrm{cm}^{-1}\right)$ of phosphate anions in $\mathrm{H}_{2} \mathrm{O}$ and $\mathrm{D}_{2} \mathrm{O}$ at $\mathrm{pH} 12.7\left(\mathrm{PO}_{4}{ }^{3-}\right), 10.1\left(\mathrm{HPO}_{4}{ }^{2-}\right)$, and $5.0\left(\mathrm{H}_{2} \mathrm{PO}_{4}{ }^{-}\right)$, and calculated harmonic frequencies of the corresponding phosphate anions by DFT/6-31+G(d,p).

- $\mathrm{PO}_{4}{ }^{3-}(\mathrm{pH} 12.7)$

\begin{tabular}{ccc}
\hline Exp. & Calc. & Assignment \\
\hline 1008 & 918 & $v_{\text {as }}\left(\mathrm{PO}_{4}\right)$ \\
$936(\text { Raman })^{2}$ & 844 & $v_{\mathrm{s}}\left(\mathrm{PO}_{4}\right)$ \\
\hline
\end{tabular}

- $\mathrm{HPO}_{4}{ }^{2-}(\mathrm{pH} 10.1)$

\begin{tabular}{rrrrc}
\hline \multicolumn{2}{c}{ Exp. } & \multicolumn{2}{c}{ Calc. } & Assignment \\
\hline $\mathrm{H}_{2} \mathrm{O}$ & $\mathrm{D}_{2} \mathrm{O}$ & $\mathrm{H}_{2} \mathrm{O}$ & $\mathrm{D}_{2} \mathrm{O}$ & \\
& & 1085 & 1072 & $\delta(\mathrm{OH})+v_{\text {as }}\left(\mathrm{PO}_{4}\right)^{4}$ \\
1080 & 1086 & 1048 & 1048 & $v_{\text {as }}\left(\mathrm{PO}_{3}\right)$ \\
& & 995 & 770 & $\delta(\mathrm{OH})^{4}$ \\
991 & 987 & 922 & 922 & $v_{\mathrm{s}}\left(\mathrm{PO}_{3}\right)$ \\
\hline
\end{tabular}

- $\mathrm{H}_{2} \mathrm{PO}_{4}^{-}{ }^{-}$(pH 5.0)

\begin{tabular}{ccccc}
\hline \multicolumn{2}{c}{ Exp. } & \multicolumn{2}{c}{ Calc. } & Assignment ${ }^{1,2,3}$ \\
\hline $\mathrm{H}_{2} \mathrm{O}$ & $\mathrm{D}_{2} \mathrm{O}$ & $\mathrm{H}_{2} \mathrm{O}$ & $\mathrm{D}_{2} \mathrm{O}$ & \\
\hline 1155 & 1177 & 1232 & 1223 & $v_{\text {as }}\left(\mathrm{PO}_{2}\right)$ \\
1076 & 1084 & 1062 & 1056 & $v_{\mathrm{s}}\left(\mathrm{PO}_{2}\right)$ \\
& & 1028 & & $\delta(\mathrm{OH})^{4}$ \\
& & 1008 & & $\delta(\mathrm{OH})^{4}$ \\
939 & 941 & 773 & & $v_{\text {as }}\left(\mathrm{P}-(\mathrm{OH})_{2}\right)$ \\
869 & - & 754 & 774 & $v_{\mathrm{s}}\left(\mathrm{P}-(\mathrm{OH})_{2}\right)$ \\
\hline
\end{tabular}

(1) Chapman, A.C.; Thirtwell, L.E., Spectra of Phosphorus Compounds - the Infra-Red Spectra of Orthophosphate, Spectrochim. Act. 1964, 20, 937-947.

(2) Niaura, G.; Gaigalas, A.K.; Vilker, V.L., Surface-Enhanced Raman Spectroscopy of Phosphate Anions: Adsorption on Silver, Gold, and Copper Electrodes, J. Phys. Chem. B 1997, 101, 9250-9262.

(3) VandeVondele, J.; Troster, P.; Tavan, P.; Mathias, G., Vibrational Spectra of Phosphate Ions in Aqueous Solutions Probed by First-Principles Molecular Dynamics, J. Phys. Chem. A 2012, 116, 2466-2474.

(4) This study. 